\title{
Exploring Factors Affecting Implementation of Public Private Partnership Housing Projects in Bauchi State, Nigeria
}

\author{
Mohammed Sani ${ }^{1}$, Abdulkadir Sani ${ }^{1}$, Usman Shuaibu Ahmed ${ }^{1}$ \\ ${ }^{1}$ Abubakar Tafawa Balewa University \\ Tawafa Belewa Way, P. M. B. 0248, Bauchi, 740272, Nigeria
}

DOI: $10.22178 /$ pos.32-8

JEL Classification: 018

Abstract. Public Private Partnership (PPP) Housing scheme in Nigeria is intended to complement government effort toward increasing housing stock and providing affordable housing in the country. However, Bauchi state government adopted the construction of 5,000 phases PPP Housing. But 6 years after the commencement of the scheme, only a few numbers of housing units were completed and commissioned. Therefore, it becomes imperative to carry out research on the impact level of those factors affecting the implementation of the scheme. The aim of the study is to investigate impact level of factors affecting the implementation of PPP housing projects in Bauchi state with a view to find out possible ways that will improve the implementation of the scheme. The descriptive and explorative research design was adopted for this study. 54 structured Questionnaires were administered to construction professional's staff under private housing developers and relevant government agencies in Bauchi state. 42 valid Questionnaires were retrieved and analysed with SPSS software. The result of the quantitative data analysis shows that creation of favourable investment environment and government support have very high Impact on the implementation of Bauchi PPP housing projects. Therefore, this study recommends that government and other stakeholders should give more attention to the creation of favourable investment environment, support in policy formulation and managerial strategies in the future for improving the implementation of PPP housing projects.

Keywords: impact; factors; public; private; partnership; housing.

\section{INTRODUCTION}

Public private partnership (PPP) is an arrangement between the public and private sectors with clear agreement on shared objectives for the delivery of public infrastructure and/or public services by the private sector that would otherwise have being provided through traditional public sector procurement [12]. The adoption of public private partnership (PPP) in housing provision in Nigeria is intended to increase urban housing stock and address housing affordability and accessibility [8]. It is an attempt to transfer some of the responsibilities of public sector housing schemes to private organizations through PPP. But records show that Bauchi State Government commence the construction of 5,000 unit of housing through PPP arrangement in 2008 [3]. However, after six years of the adoption of PPP Housing project in Bauchi State, only 228 housing units were completed and commissioned for habitation in 2015 [3]. This is an indication that there are some factors that hindered the successful implementation of the Bauchi PPP housing scheme. Therefore, this requires thorough investigation in order to find out the magnitude or severity of their effects in Bauchi PPP housing projects. Authors [7] also observed that there are little achievements recorded in most of the Nigerian cities by public private partnership housing scheme to address the shortfall in the provision of affordable housing in the country. PPP housing implementation challenges were recorded in various states in Nigeria $[4,7,8,14]$. But there was no non-study that investigate impact level of factors affecting the implementation of PPP housing projects which left a gap to be filled. 


\section{Factors Affecting the Implementation of PPP Projects}

Authors [11] found that the success or failure of a PPP project is dependent on a number of factors that can be classified into four groups: The competence of the government, the selection of an appropriate concessionaire, appropriate risk allocation between the public and private sectors and sound financial package.

Government plays an important role in the development and management of a PPP project. The inappropriate involvement of government to manage PPP projects may lead to project failure. Authors [11] further summarised the roles of government in PPP project into five subfactors: Create favourable investment environment, Establish adequate legal/regulatory framework, To select a suitable concessionaire, Establish a coordinating and supportive authority and Be actively involved in the project life-cycle phases.

A concessionaire is principle participant in a PPP project, its responsibilities include the financing, design, construction, operation, and maintenance of the infrastructure facilities and the transferring of the facilities to the client in operational condition at the end of the concession period [11]. Concessionaire selection was subdivided into the procurement process, tender evaluation method and evaluation criteria.

A risk is defined as any factor, event or influence that threatens the successful completion of a project interim of cost, time and quality [12]. Researchers [11] found that PPP project is characterised by high level of risks due to the long concession period, and the diversity of participants involved in the partnership and risks associated with PPP projects can be categorized into political risks, financial risks, construction risks, operation and maintenance risks, market and revenue risks and legal risks.

Construction is capital-intensive activities which require a sound financial plan for its successful implementation. Authors [11] concluded that a sound financial plan for a PPP should have an appropriate mix of equity and debt, a financing strategy that is based on the considerations of project risks, project conditions, and financing sources and some government supports such as the minimum guaranteed revenue, the flexibility in tariff structure, the financial support, and force majeure protection may be required to make a PPP project financially viable.

\section{METHODOLOGY}

Research design refers to the framework for the collection and analysis of data and the choice of the research design reflect the decision about priority being given to a range of dimensions of the research process [10]. The descriptive and explorative research design was adopted for this study. This research collected data from primary source using Questionnaires. While secondary data was collected from previous related literature and Bauchi State Ministry of Lands and Housing records on Bauchi PPP housing schemes to support and complement the findings of the primary data. A 5-point Likert scale was employed in the questions to indicate the degree of agreement by the respondents on factors affecting the implementation of PPP housing project. "1" represented strongly disagreed, "2" represented disagreed, " 3 " represented Not decided, " 4 " represented agreed and " 5 " represented strongly agree for section B. 54 structured Questionnaires were administered to construction professionals staff under private housing developers and relevant government agencies in Bauchi state. 42 valid Questionnaires were retrieved and analysed with SPSS software.

\section{Impact level of Factors}

Authors [5] assert that ordinal scale is used to determine the level of impact based on the mean rating (MR) computation. The scale was divided into five categories; from $1-1.8=$ very low impact, $1.8-2.6=$ low impact, $2.6-3.40=$ small impact, $3.40-4.20=$ high impact and $4.20-5.00=$ very high impact. The scale was used to determine the impact level of factors affecting the implementation of Bauchi PPP housing projects base on the mean obtained in the analysis. Therefore any factor that has a mean rating (MR) within these ranges will be categories appropriately as shown below:

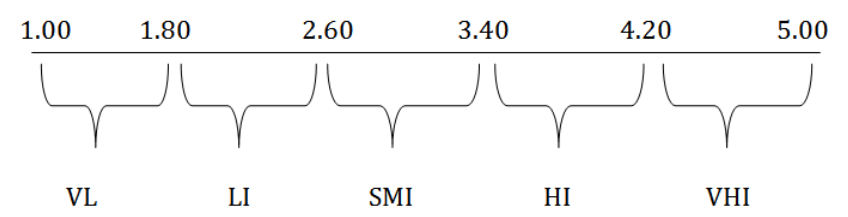

Figure 1 - Evaluation Scale [5]

\section{RESULTS AND DISCUSSION}

The Table 1 present the result of the professional background of the respondents. 
Table 1 - Respondents professional background

\begin{tabular}{|l|c|r|r|r|}
\hline \multicolumn{1}{|c|}{ Staff } & Frequency & \multicolumn{1}{c|}{ Percent } & \multicolumn{1}{c|}{ Valid Percent } & \multicolumn{1}{c|}{ Cumulative Percent } \\
\hline Architects & 10 & 23.8 & 23.8 & 23.8 \\
\hline Builder & 8 & 19.0 & 19.0 & 42.9 \\
\hline Estate Valuer & 9 & 21.4 & 21.4 & 64.3 \\
\hline Quantity surveyor & 15 & 35.7 & 35.7 & 100.0 \\
\hline Total & 42 & 100.0 & 100.0 & \\
\hline
\end{tabular}

It shows that there are 10 Architect (23.8\%), 8 Builder (19.0\%) , 9 Estate valour (21.4\%) and 15 Quantity Surveyor (35.7 \%) respectively.
The Table 2 shows Academic Qualification of the respondents.

Table 2 - Academic qualification of the respondents

\begin{tabular}{|l|c|r|r|r|}
\hline Qualification & Frequency & Percent & \multicolumn{1}{|c|}{ Valid Percent } & \multicolumn{1}{c|}{ Cumulative Percent } \\
\hline Phd & 2 & 4.8 & 4.8 & 4.8 \\
\hline M. Sc. /M. Tech. & 8 & 19.0 & 19.0 & 23.8 \\
\hline B. Sc. /B. Tech. / HND & 27 & 64.3 & 64.3 & 88.1 \\
\hline OND & 3 & 7.1 & 7.1 & 95.2 \\
\hline Others & 2 & 4.8 & 4.8 & 100.0 \\
\hline Total & 42 & 100.0 & 100.0 & \\
\hline
\end{tabular}

B. Sc. / B. Tech. / HND has the highest frequency of $27(64.3 \%)$ then follows by M. Sc. / M. Tech. with the frequency of 8 (19\%), PhD 2 (4.8\%) and other $2(4.8 \%)$ respectively.
The Table 3 shows the frequency and percentages of the various roles of the respondents in PPP projects.

Table 3 - Respondents' role in PPP projects

\begin{tabular}{|l|c|r|r|r|}
\hline \multicolumn{1}{|c|}{ Role } & Frequency & Percent & \multicolumn{1}{c|}{ Valid Percent } & \multicolumn{2}{c|}{ Cumulative Percent } \\
\hline Developer & 16 & 38.1 & 38.1 & 38.1 \\
\hline Government & 20 & 47.6 & 47.6 & 85.7 \\
\hline Consultant & 6 & 14.3 & 14.3 & 100.0 \\
\hline Total & 42 & 100.0 & 100.0 & \\
\hline
\end{tabular}

It revealed that Governments Agency (public) have the highest frequency of $20(47.6 \%)$. Developers have the frequency of 16 (38.1\%). The respondents from consultants have the frequency of $6(14.3 \%)$

The Table 4 shows the overall ranking of factors affecting the implementation of Bauchi PPP housing project. The table 4 revealed that create favourable investment environment and govern- ment support have a very high impact on the implementation of Bauchi PPP housing project with the mean of 4.29 and 4.24 and therefore, ranked number 1 and 2 respectively.

These factors are very crucial and should be given appropriate consideration in the implementation of Bauchi PPP housing project.

Table 4 - Impact Level of factors affecting the implementation of Bauchi PPP housing projects

\begin{tabular}{|l|c|c|c|c|c|}
\hline \multicolumn{1}{|c|}{ Factors } & Sum & Mean & S. D & Ranking & Impact Level \\
\hline Create favourable investment environment & 180 & 4.29 & .554 & 1 & Very High \\
\hline Government supports & 178 & 4.24 & 1.078 & 2 & Very High \\
\hline Establish adequate legal/regulatory framework & 176 & 4.19 & .505 & 3 & High \\
\hline Project financing sources & 175 & 4.17 & .794 & 4 & High \\
\hline Project financial viability & 174 & 4.14 & 1.117 & 5 & High \\
\hline
\end{tabular}




\begin{tabular}{|l|c|c|c|c|c|}
\hline \multicolumn{1}{|c|}{ Factors } & Sum & Mean & S. D & Ranking & Impact Level \\
\hline Project financing strategies & 173 & 4.12 & .772 & 6 & High \\
\hline Tender evaluation method & 169 & 4.02 & .563 & 7 & High \\
\hline To select a suitable concessionaire & 168 & 4.00 & .733 & 8 & High \\
\hline Establish a coordinating \& supportive authority & 167 & 3.98 & 1.000 & 9 & High \\
\hline Being actively involved in the project life-cycle & 167 & 3.98 & .749 & 10 & High \\
\hline Political risks & 161 & 3.83 & 1.342 & 11 & High \\
\hline Evaluation criteria & 155 & 3.69 & .975 & 12 & High \\
\hline Procurement process & 154 & 3.67 & 1.004 & 13 & High \\
\hline Financial risks & 136 & 3.24 & 1.511 & 14 & Small \\
\hline Legal risks & 133 & 3.17 & 1.228 & 15 & Small \\
\hline Market and revenue risks & 131 & 3.12 & 1.292 & 16 & Small \\
\hline Construction risks & 126 & 3.00 & 1.414 & 17 & Small \\
\hline Operation and maintenance risks & 124 & 2.95 & 1.229 & 18 & Small \\
\hline Environmental/land risks & 121 & 2.88 & 1.234 & 19 & Small \\
\hline
\end{tabular}

\section{CONCLUSION}

As mentioned earlier, the purpose of this research is to investigate factors affecting the implementation of Bauchi PPP housing projects. To achieve the stated aim of the study the following objective was set. To Identify and assess the impact level of the factors affecting the implementation of the projects. Therefore, the conclusion will be made base on these objectives. The objectives were achieved by information collected from PPP housing record from Bauchi State Ministry of Lands and Housing in 2014, an extensive review of literature and questionnaire survey. The result of the assessment of the nineteen factors that were identified shows that Creation of favourable investment environment and Government Support have a very high impact and consider as most powerful factors affecting the implementation of Bauchi PPP housing projects. Public private partnership housing projects in Nigeria is relatively new. As such, mistakes can easily be made due to inexperience. The little experience acquired during the execution of few PPP projects should be used to enhance the implementation of the scheme in the future. In addition, the recommendations of various research conducted on problems and most importantly the prospects of PPP housing projects should be utilised judiciously to facilitate the successful implementation of the scheme in the future. The government should create a favourable investment environment that will be supported by stable legal and economic framework for advance and sustainable implementation of PPP housing projects. Government support in the form of project specific assistance, loan guarantee, guarantee minimum revenue and tax reduction should be given to the private developers. This will increase the financial viability of the project and assured private developers the likely revenue that may accrue from PPP projects if undertaken in any concession project.

\section{REFERENCES}

1. Aribigbola, A. (2008). Housing Policy Formulation in Developing Countries: Evidence of Programme Implementation from Akure, Ondo State, Nigeria. Journal of Human Ecology, 23(2), 125-133. doi: 10.1080/09709274.2008.11906063

2. Australian Housing and Research Institute. (2004). Measuring housing affordability. Retrieved from https://www.ahuri.edu.au/_data/assets/pdf_file/0016/2923/AHURI_RAP_Issue_45_Measuring _housing_affordability.pdf

3. Bauchi State Ministry of Lands and Housing. (2015). Record of Bauchi Public Private Partnership Housing Projects. Bauchi, Nigeria.

4. Dalil, M. \& Yamman, U. (2013). Private sector participation in the provision of urban services: an overview of housing supply in Minna, Niger state, Nigeria. International Journal of Humanities and Social Science Invention, 2(4), 51-58. 
5. Durdyev, S., \& Mbachu, J. (2011). On-site labour productivity of New Zealand construction industry: Key constraints and improvement measures. Australasian Journal of Construction Economics and Building, 11(3), 18-33

6. Greene, M., \& Rojas, E. (2008). Incremental construction: a strategy to facilitate access to housing. Environment and Urbanization, 20(1), 89-108. doi: 10.1177/0956247808089150

7. Ibem, E. O. \& Aduwo, E. B. (2012). Public-Private Partnerships (PPPs) in Urban Housing in Nigeria: Evidence from Ogun State. International Journal of Architecture and Urban Development, 2(2), 514.

8. Ibem, E. O. (2011). Public-Private Partnership (PPP) in Housing Provision in Lagos Megacity Region, Nigeria. International Journal of Housing Policy, 11(2), 133-154. doi: 10.1080/14616718.2011.573204

9. Jamali, D. (2004). Success and failure mechanisms of public private partnerships (PPPs) in developing countries. International Journal of Public Sector Management, 17(5), 414-430. doi: 10.1108/09513550410546598

10. Kuroshi, P. A., Lawal, M. (2014). Study of internal factors affecting labour productivity in medium sized construction firms in Nigeria. International Journal of Education and Research, 2(12), 8392.

11. Kwak, Y. H., Chih, Y., \& Ibbs, C. W. (2009). Towards a Comprehensive Understanding of Public Private Partnerships for Infrastructure Development. California Management Review, 51(2), 51-78. doi: $10.2307 / 41166480$

12. Ministry of Finance and Economic Development. (2006). A Condensed Version of the PPP Guidance Manual. Retrieved from http://mof.govmu.org/English/Documents/financial\%20management\%20kit/PPPManualcond ensedver.pdf

13. Miraftab, F. (2004). Public-Private Partnerships. Journal of Planning Education and Research, 24(1), 89-101. doi: 10.1177/0739456x04267173

14. Ukoje, J. E. \& Kanu, K. U. (2014). Implementation and the Challenges of the Mass Housing Scheme in Abuja, Nigeria. American International Journal of Contemporary Research, 4(4), 209-218.

15. UN-Habitat. (2014). State of African Cities 2014. Re-imagining sustainable urban transitions. Retrieved from https://www.citiesalliance.org/sites/citiesalliance.org/files/SoAC2014.pdf

16. Valipour, A., Yahaya, N., Md Noor, N., Kildienė, S., Sarvari, H., \& Mardani, A. (2015). A fuzzy analytic network process method for risk prioritization in freeway PPP projects: an Iranian case study. Journal of Civil Engineering and Management, 21(7), 933-947. doi: 10.3846/13923730.2015.1051104 